\title{
THE PREPAREDNESS FOR THE COVID-19 PANDEMIC MANAGEMENT IN INDONESIA
}

\author{
Kesiapsiagaan Penanganan Pandemi COVID-19 di Indonesia \\ Muchammad Iqbal Firmansyah', " $F a j a r$ Rahmanto', Deni Setyawan ${ }^{1}$ \\ ${ }^{1}$ Department of Government Affairs and Administration, Universitas Muhammadiyah Yogyakarta, Indonesia \\ ${ }^{*}$ Correspondence: fajarrahmanto1@gmail.com
}

\begin{abstract}
Background: The increasing number of COVID-19 cases requires health worker preparedness on the frontline of providing healthcare services to people infected with COVID-19. As many health workers have been infected with COVID-19, this worsens the COVID-19 management. In Indonesia, until 27 April 2020, at least 47 nurses were positive COVID-19, and the number of nurses under supervision and treatment were 546 and 44 people, respectively.

Aims: This study analyzed health workers' preparedness in managing the pandemic to reduce the risk of infection through medical services provided.

Methods: This study used a descriptive qualitative method with a non-systematic literature review approach. Secondary data were collected from other previous studies and public documents related to COVID-19 disaster management in Indonesia. They were then analyzed using a thematic analysis to identify patterns and understand data information better.

Results: The results show that the ratio of health workers who have managed COVID-19 patients was not ideal. In Indonesia, the ratios of doctors and nurses involved in the COVID-19 management were 0.4 and 2.1, respectively. It was far beyond the ration in developed countries which pose the ratio of doctors and nurses were 2.5 and 5.5, respectively. Besides, most a number of adequate medical devices have been distributed to referral hospitals in almost every province. They have received 1,997,684 pieces of surgical masks 1,659,955 units of Personal Protective Equipment (PPE), and 1,011,130 units of Rapid Test kits distributed to various regions, provinces, and districts, as well as hospitals across Indonesia.

Conclusion: The number of human resources, operational standards, and health care facilities affect preparedness for providing healthcare services to manage the pandemic disaster.
\end{abstract}

Keywords: health workers, medical services, pandemic disaster management, COVID-19.

\begin{abstract}
ABSTRAK
Latar Belakang: Peningkatan kasus COVID-19 menuntut kesiapsiagaan dari tenaga kesehatan sebagai garda terdepan untuk memberikan pelayanan medis dalam penanganan korban terinfeksi COVID-19. Banyaknya petugas medis yang telah terinfeksi COVID-19 menjadikan penangan COVID-19 semakin sulit. Di Indonesia, sampai tanggal 27 April 2020, setidaknya telah ada 47 perawat dinyatakan positif dengan jumlah perawat berstatus ODP dan PDP masing-masing berjumlah 546 orang dan 44 orang.

Tujuan: Penelitian ini mengidentifikasi kesiapsiagaan penanganan pandemi dalam menekan potensi resiko akibat wabah COVID-19 melalui layanan medis yang diberikan.

Metode: Penelitian menggunakan kualitatif deskriptif dengan pendekatan studi pustaka non sistematis. Data sekunder yang dikumpulkan berupa referensi terdahulu serta dokumen publik terkait dengan penanganan bencana COVID-19 di Indonesia. Teknik analisa data menggunakan tematik analisis untuk identifikasi pola dan memahami data informasi.

Hasil: Rasio tenaga kesehatan yang menangani pasien COVID-19 belum ideal. Rasio jumlah tenaga dokter dan tenaga perawat masing-masing 0,4 dan 2,1. Rasio ini masih jauh tertinggal dari negara maju dimana rasio tenaga kesehatannya sudah diatas angka 2,5 tenaga dokter dan 5,5 untuk tenaga perawat. Kemudian, secara umum rumah sakit rujukan penanganan COVID-19 hampir di setiap provinsi yang telah didukung dengan distribusi alat material kesehatan ke berbagai daerah, provinsi dan kabupaten, serta rumah-rumah sakit yang membutuhkan di seluruh wilayah Indonesia berupa masker bedah (1.997.684 buah), APD sebanyak 1.659.955 unit, ditambah dengan alat rapid test sebanyak 1.011 .130 unit.

Kesimpulan: Kesiapsiagaan dalam memberikan layanan medis terhadap penanganan bencana pandemi dipengaruhi oleh jumlah SDM, standar operational dan sarana-prasarana fasilitias kesehatan.
\end{abstract}

Kata kunci: Tenaga Kesehatan; Pelayanan Medis; Penanganan Bencana Pandemi; COVID-19 


\section{INTRODUCTION}

Coronavirus is a virus transmitted through a pathogenic infection of the Severe Acute Respiratory Syndrome Coronavirus 2 (SARS-CoV-2) that has firstly appeared in Wuhan, China, and spread throughout the world (Adnan et al., 2020). This virus is now known as Coronavirus Disease 2019 (COVID-19) affecting the lives of global society (Arshad et al., 2020). In Indonesia, COVID-19 firstly emerged at the beginning of March 2020 when the government claimed that two Indonesian citizens got infected. Due to its rapid spread, several regions in Indonesia have been vulnerable, such as Jakarta, Surakarta, Depok, and several others (Nanggala, 2020). Two months later, the National COVID-19 Handling Task Force reported the trend of positive COVID-19 cases in Indonesia has continued increasing every day. The number of cases reached 1,528 with an average of 100 new cases every day from 18 - 30 March 2020. Then, on April 30, 2020, the total cases increased to 10,118 cases, which reached 300 new cases from 3-11 April 2020, and an average increase of new cases reached 400 cases per day on 15-27 April 2020. On May 31, 2020, the total cases in Indonesia rose to 26,473 , with daily average cases of 500 per day from 1- 13 May 2020 and increased again to 600 cases per day from 17-29 May 2020, with the highest increase of 900 cases on May 21, 2020. However, what is even more depressing is the increasing number of health workers infected with COVID-19, until 27 April 2020, at least 47 infected nurses, 546 people under supervision, and 44 patients under treatment (Amindoni, 2020).

Health workers as the front liners in healthcare services, who have significant roles and responsibilities for taking care victims during worse disasters, need to be more prepared (Septiana and Fatih, 2019). One of the strategies is to take responsive actions in controlling people infected to prevent human-to-human transmission (Lai et al., 2020). Thus, effective disaster management can be done by increasing the intensity of coordination and communication, eliminating ego-sectoral attitudes, and having competent human resources (Ariyanto, 2018).

Non-natural disaster events may result in the mortality rate of 1.5 times higher than natural disasters (Pane et al., 2018). Thus, effective, significant, and impactful disaster management is required by meticulously planning disaster mapping, the placement of health workers, and clear division of works (Faradilla, 2018). Regarding these plans, the health sector already has regulations and service standards for health workers supported by public participation in disaster management (Hutagaol, 2019). Nevertheless, the lack of institutional preparedness for the occurrence of disasters leads to poor disaster preparedness (Huriah and Farida, 2010). Considering a high gap of knowledge about COVID-19 management, community organizations need to contribute to create a database related to COVID-19 at the local, regional, and international levels (Ling et al., 2020).

Many studies have investigated COVID-19 since the outbreak has widely spread to all countries worldwide and posed a risk of disasters on global public health. A study conducted by Ling et al. (2020), for instance, has suggested that to prevent the widespread of COVID-19 from infected patients to uninfected people, the community should maintain hand hygiene, put on standard N-95 masks and personal protective equipment (PPE). Furthermore, the government needs to establish a clear set of protocols and prevention procedures, as well as communication and cooperation 
with all stakeholders (Ling et al., 2020). Research by Jiang et al. (2020) shows that the COVID-19 are quickly transmitted through interaction and close contact between humans (Jiang et al., 2020). Research by Lai et al. (2020) has stated that the emergence of SARS-CoV-2 and novel coronavirus (2019-nCoV) in China has posed a serious threat of global community health (Lai et al., 2020).

Since COVID-19 has caused abundant problems and negative impacts on global public health, the preparedness of health workers in providing available and urgent healthcare services is crucial. Hence, this study aimed to analyze the preparedness of health workers in providing healthcare services to reduce the potential risk of transmission between humans. This study looked at various literature studies, previous research, documents, and many articles related to the COVID-19 pandemic management in Indonesia. Since a good system of pandemic management is expected to prevent the widespread of COVID-19, this study reviewed the data sources in terms of standard management procedures, human resources, and health facilities.

\section{METHOD}

This study used a descriptivequalitative method with a literature study approach to obtain data and information. $A$ descriptive-qualitative study could provide in-depth descriptions using qualitative research data of health workers' preparedness in providing healthcare services during the pandemic (Bandur, 2019). Meanwhile, the literature study approach obtained research information from books, the internet, and previous relevant research (Farida, 2019).

A non-systematic literature review was employed to collect secondary data, such as documents of health protocols on COVID-19 management released by the
COVID-19 Handling Taskforce of Indonesia and WHO. Additionally, this study used data on the Kompas Research and Development Center website which released the ratio of health workers for managing COVID-19 in various countries, as well as data from the Indonesian Ministry of Health regarding the number of infrastructure and health facilities in the COVID-19 management. The data were retrieved from the Task Force for the Acceleration of Handling COVID-19 (covid19.go.id), the Indonesian Ministry of Health (kemenkes.go.id), and Kompas Research and Development Center (kompas.com) from March 1 to May 31, 2020, when positive cases continued to increase significantly.

The data analysis technique used was a thematic analysis to identify patterns of data or the literacy of information (Heriyanto, 2018). The analysis was carried out by understanding information from the data sources and then codifying data for classification according to the themes (SOP, Health Human Resources, and Health Facilities). Finally, the step of data analysis was drawing out conclusions or verification of qualitative research data by interpreting meaning through the data reflection.

\section{RESULTS AND DISCUSSION}

Indonesia has categorized the COVID-19 pandemic as a non-natural disaster or a disease outbreak. It has obliged a systemic effort to overcome, suppress the spread, and decline the number of the cases. Non-natural disaster events may result in a higher mortality rate than natural disasters (Pane, et. al., 2018). Therefore, it becomes a joint authority and responsibility between the central and local governments to establish public health protection from the threats of COVID-19 or potential health risks that can lead to public health emergencies. Though the health 
sector already has regulatory standards related to health services, the disaster management needs to be strengthened through community participation (Hutagaol, 2019). In the COVID-19 disaster management, the government needs to pay attention to some steps that have been carried out, especially in implementing the management policy. To quickly deal with COVID-19, it requires disaster management planning; this planning is expected to reduce the disease transmission and mortality rate. One of the mitigation measures undertaken by the government was providing medical services to health workers in handling positive confirmed patients.

\section{Standard Operating Procedures in COVID-19 Management}

The rapid COVID-19 transmission through human interaction has resulted in a risk of death threatening the whole community health (Jiang et al., 2020; Lupia et al., 2020). Since it gives negative consequences, appropriate standard procedures in handling medical services for infected patients are necessary. The medical service standard is used as a guide to provide treatment measures that are useful to prevent the transmission from one patient to another or to health workers who make close contact with them. Thus, the standard procedure can support safe medical services, both for COVID-19 patients and health workers. Standard Operating Procedures (SOPs) for emergency treatment have been proved to affect the preparedness of health workers

Table 1. Medical Service Standard Procedures for Handling COVID-19 Patients.

\begin{tabular}{ccl}
\hline Medical Services & \multicolumn{1}{c}{ Standard Procedures } \\
\hline Placement & - Performing immediate isolation to suspected and confirmed \\
Management & patients. \\
& - Explaining every action that will be given to patients to reduce \\
& stress and anxiety. \\
& - Placing patients in separate rooms if conditions permit. \\
& - Separating each suspected and confirmed case. \\
& - Setting the distance between patients at least 1 meter. \\
Environmental & - Not placing more than one patient in one bed. \\
Management & Limiting the movement of patients to reduce the possibility of \\
& infection in health care facilities. \\
& - Planning patient transfer if necessary. Instructing health workers \\
& and visitors to wear personal protective equipment (PPE). \\
& Conducting periodic cleaning and disinfection around the \\
& environment. & In carrying out medical service procedures in the coviD-19 \\
& disaster management, each health worker has put on appropriate \\
& personal protective equipment (PPE) when screening patients at \\
& the triage point. \\
\hline Visitor & - & Limiting the number of visitors per patient. \\
Management & Wearing personal protective equipment and recording each visit to \\
& healthcare facilities.
\end{tabular}


in facing disasters (Gultom, 2012). Thus, internal regulations regarding safety in handling disaster victims need to be formulated by hospitals (Berliana and Widowati, 2019).

In carrying out medical service procedures in the COVID-19 disaster management, each health worker has put on appropriate personal protective equipment (PPE) when screening patients at the triage point. Besides, health workers have to provide medical masks to all patients who show flu-like symptoms or report possible COVID-19 infections. Furthermore, they need to always remind all patients to practice good respiratory and hand hygiene.

Based on Table 1, the procedures for handling COVID-19 patients must be done through the management of patient placement, environmental management, and visitors management. Confirmed positive patients should be placed in at least one meter from other patients to minimize physical contact. Then, the standards of environmental management could be conducted by limiting the movement of patients to minimize the infection transmission in health care facilities. It is a strategic step in controlling people who are temporarily infected to prevent transmission between humans (Lai et al., 2020). Furthermore, the visitor management should enforce limiting the number of COVID-19 visitors and obliging them to wear PPE. To prevent transmission from infected patients, visitors wear standard PPE and a clear set of protocols and procedures (Ling et al., 2020). Less or no institutional preparation for a disaster will cause weak preparedness in dealing with emergencies (Huriah and Farida, 2010). Although the health sector already has regulations and service standards for health workers, public participation is another important aspect in disaster management (Hutagaol, 2019).
The rapid COVID-19 transmission and the increasing number of victims have become a concern for the community and the Indonesian government. To respond to the threats, it is necessary to take strategic steps by preparing and strengthening the capacity of health workers at hospitals, laboratories, and other health care facilities. Therefore, good clinical governance is vital to provide guidance for health workers and the public about prevention measures and actions to deal with the COVID-19 disaster. Good clinical governance aims to reduce and stop the virus transmission and the level of severity and mortality due to the pandemic. The COVID-19 pandemic requires a comprehensive study on the implementation of good clinical governance and consistent application (Djasr, 2020). Clinical governance in the COVID-19 disaster management includes indirect public communication, information, and education (CEI); management and organization of patients and recommendation of prospective patients; governance of rapid tests and other laboratory examinations; patient management at hospitals; quarantine and isolation governance; and death management All need to be executed with good governance, and thus the stakeholders are ready to face disasters, such as casualties, property losses, and psychological disorders that can be reduced significantly (Hadi, Agustina, and Subhani, 2019). Table 2 shows the clinical management of COVID-19 pandemic in Indonesia.

The COVID-19 transmission through close contact and droplets makes health workers vulnerable to infection. In reducing this risk, good clinical governance in medical services for the prevention and mitigation of the pandemic disaster is essential in health care facilities. Clinical management focuses on handling the COVID-19 pandemic disaster with standard precautions that must be implemented in the entire health care facilities. 
Table 2. Good Clinical Governance: COVID-19 Pandemic Disaster Management.

\begin{tabular}{|c|c|}
\hline Good Clinical Governance & Evidence \\
\hline $\begin{array}{l}\text { Indirect Communication, } \\
\text { Information, and Education } \\
\text { (CIE) to the community }\end{array}$ & $\begin{array}{l}\text { The public can contact the National Disaster } \\
\text { Management Agency call center (117), the Indonesian } \\
\text { Ministry of Health (119 ext. 9), and other information } \\
\text { channels, such as DKI 112, Gojek-Halodoc telemedicine, } \\
\text { and the National Disaster Management Agency website } \\
\text { on https://www.covid19.go.id/ and the Indonesian Ministry } \\
\text { of Health website on https://covid19.kemkes.go.id }\end{array}$ \\
\hline $\begin{array}{l}\text { Governance of Rapid Tests } \\
\text { and Laboratory Inspections }\end{array}$ & $\begin{array}{l}\text { Rapid Test (RT) antibodies or antigens are performed to } \\
\text { people who have direct contact with positive patients. } \\
\text { Besides, rapid test is used to detect ODP and PDP cases } \\
\text { in areas that do not have RT-PCR inspection facilities. } \\
\text { Examination uses rapid test to People without symptoms } \\
\text { (OTG), People in Oversight (ODP), and Patients in } \\
\text { Oversight (PDP). }\end{array}$ \\
\hline $\begin{array}{l}\text { Patient Management at } \\
\text { Hospitals }\end{array}$ & $\begin{array}{l}\text { - Treatment of COVID-19 patients } \\
\text { - Indications of patients who need a mechanical } \\
\text { ventilator } \\
\text { - Conditions of discharged COVID-19 patients }\end{array}$ \\
\hline Quarantine Management & $\begin{array}{l}\text { - } \text { Home Quarantine } \\
\text { - Self-Isolation } \\
\text { - } \text { Quarantine Special Facilities } \\
\text { - } \text { Hospital Quarantine } \\
\text { - } \text { Regional Quarantine }\end{array}$ \\
\hline $\begin{array}{l}\text { Management of Dead } \\
\text { Patients }\end{array}$ & $\begin{array}{l}\text { The management of dead COVID-19 patients is carried } \\
\text { out by prioritizing continuously the safety of health } \\
\text { workers and the environment according to the COVID-19 } \\
\text { corpse scouring procedures. } \\
\text { - First, officers must use the PPE when handling the } \\
\text { patient who died during the transmission. } \\
\text { - Second, the patient's body must be completely } \\
\text { wrapped in a body bag that is not easily penetrated. } \\
\text { - Third, the body wrapped should not be opened } \\
\text { again, then delivered in a special hearse, and buried } \\
\text { no more than four hours. } \\
\text { Fourth, officials must provide an explanation to the } \\
\text { family about the special management of dead } \\
\text { patients due to infectious diseases as this } \\
\text { management procedure brings the sensitivity } \\
\text { towards religion, customs, and culture. }\end{array}$ \\
\hline
\end{tabular}

Therefore, it can provide safe medical services for all patients and reduce the risk of continuous infection. Besides, improving the quality of public services needs to be supported by increasing the competence of human resources, the availability of complaint services, the completeness of information media, and the guarantee of service facilities and infrastructure (Gani, 
2019; Purnamasari and Kushandajani, 2019).

Standard precautions in handling COVID-19 patients include performing hand and breathing hygiene, using personal protective equipment (PPE) according to risk, prevention of injuries caused by sharp objects and syringes, and setting safe management of medical waste according to procedural routines and cleaning environment, linen sterilization and patient care. To prevent the COVID-19 transmission from infected patients, the government do some protocols such as maintaining hand hygiene, ensuring the availability of $\mathrm{N}-95$ masks and personal protective equipment (PPE) according to standards, formulating a clear set of protocols and prevention procedures, as well as building communication and cooperation among stakeholders (Ling et al., 2020). Furthermore, the pandemic handling procedure includes ensuring early identification and control of sources using clinical triage in health care facilities. It aims to prevent the transmission of pathogens to medical personnel and other patients. Additionally, administrative control needs to be carried out as a top priority in the infection prevention and control (PPI) which includes the provision of infrastructure policies and procedures for preventing, detecting, and controlling infections during medical treatment. This step will be useful if it starts from anticipating the movement of patients from the time they first arrive until they leave healthcare facilities. Thus, internal regulations regarding facility management and safety and staff competency improvement through training need to be prepared by hospitals (Berliana and Widowati, 2019).

Moreover, environmental control and engineering can be performed as well to ensure adequate environmental ventilation in all areas. For example, hospitals can set a physical distancing seat in at least 1 meter between one patient and another

The Preparedness for... including health workers (if they are not using PPE). These environmental engineering control activities can reduce the spread of several pathogens during the delivery of health services. The rate of disaster events requires the preparedness of health workers as the front-liners to provide health services to victims during disasters (Septiana and Fatih, 2019).

\section{Human Resources in the COVID-19 Pandemic Management}

An established health system that is supported by strong state finance will provide the government readiness to respond to a pandemic disaster. Country responsiveness in facing a pandemic is determined by their ability to suppress the spread rate, level of health facilities, the ability to deal with infected patients, and the capacity to manage and mobilize resources quickly in dealing with the crisis effects. The state's inability to deal with a pandemic disaster will fail to put a halt to the spread of a pandemic, and thus it leads to a human tragedy (Mas'udi and Winanti, 2020). The Indonesian government still faces a fundamental problem in implementing a fair and equitable medical service concerning the unfair number and distribution of health workers at the primary level (Djasr, 2020). Besides, the number of health workers in Indonesia is still lacking to support the smooth running of health services for emergencies that require human resources, facilities, and infrastructure (Musyarofah et al., 2019).

To respond to the COVID-19 pandemic, the government requires readiness and responsive action to set optimal health personnel and medical service governance with information, procedures, and protective equipment for safe and effective work. Health workers play an essential role in the implementation of emergency responses to COVID-19 outbreaks. They also become the 
backbone of the country's defence to limit and control the spread of diseases. To improve the effectiveness of disaster management, it needs to focus on improving coordination and communication, reducing ego-sectoral, and strengthening human resource competency in implementing the disaster management (Ariyanto, 2018). At the forefront, health workers provide COVID-19 services, which are usually carried out in highrisk situations. Health workers are at higher risk of being infected with COVID-19 while protecting public health. They are at risk of exposure to hazards such as psychological stress, fatigue, mental fatigue, or stigma. Therefore, it takes careful planning to allocating medical personnel and clear division of work that demands their readiness in providing medical services to victims in a disaster (Faradilla, 2018; Septiana and Fatih, 2019). The pandemic disaster management requires a large number of doctors and nurses to stay in 24 hours at hospitals. Their struggle in handling the COVID-19 pandemic disaster deserves a high appreciation since they fully dedicate their time and energy (Tosepu et al., 2020). Dedication is the consistency of one's commitment to the success of specific tasks or goals. It has noble values and involves powerful beliefs. Health worker dedication is vital to deal with performing duties during the pandemic. Thus, the central government and the regional one needs an optimal policy to protect health workers (Nasution, 2020)
Figure 1 shows that the ratio of Indonesian health workers involved in the management of the COVID-19 pandemic is 0.4 for doctors and 2.1 for nurses. It means that only four doctors exist to provide services per 10,000 residents. In other words, each doctor must take care of 2,500 residents. As for nurses, a ratio of 2.1 means that 21 nurses serve at an average population of 10,000 . It indicates that each nurse must handle as many as 476 people. This condition is very different from the United States and several other European countries (Spain, Italy, Germany, France, and the United Kingdom) which have the high number of COVID-19 pandemic victims, but the ratio of health workers is above 2.5 for physicians and 5.5 for nurses. It means that per at least 10,000 inhabitants, they prepare 25 doctors and 55 nurses with an average number of one doctor handling 400 people and one nurse treating 181 people. In short, the ratio between the number of health workers and the number of infected people in Indonesia are still not ideal compared to some developed countries with the higher number of cases. To provide clear data, Table 3 illustrates a comparison among some neighbouring countries like Malaysia and Singapore.

\begin{tabular}{|c|c|c|}
\hline Country & Doctor & Nurse \\
\hline USA & 2.5 & 8.6 \\
\hline Spain & 4.1 & 5.5 \\
\hline Italy & 4.1 & 5.9 \\
\hline Germany & 4.2 & 13.2 \\
\hline France & 3.2 & 9.7 \\
\hline England & 2.8 & 8.3 \\
\hline China & 1.8 & 2.3 \\
\hline Iran & 1.1 & 1.9 \\
\hline Turkey & 1.8 & 2.6 \\
\hline Belgium & 3.3 & 11.1 \\
\hline Indonesia & 0.4 & 2.1 \\
\hline
\end{tabular}

Source: Kompas Research and Development Data, 2020

Figure 1. The Ratio of Health Workers to COVID-19 Affected Countries

(Per 1,000 Population) 
Table 3. Ratio of Health Workers and Positive COVID-19.

\begin{tabular}{cccccc}
\hline Country & \multicolumn{2}{c}{ Ratio of Doctors } & \multicolumn{3}{c}{ Positive Covid-19 } \\
\cline { 3 - 5 } & & & March 31 & April 29 & May 31 $^{\text {th }}$ \\
\hline Indonesia & 0.4 & $4: 10.000$ & 1.528 & 10.118 & 25.773 \\
Malaysia & 0.1 & $10: 10.000$ & 2.626 & 5.945 & 7.762 \\
Singapore & 0.1 & $10: 10.000$ & 879 & 14.951 & 34.366 \\
\hline
\end{tabular}

Hence, it is essential to pay attention to developing the capacity of health workers in responding to disaster management (Septiana and Fatih, 2019). Management of health workers in dealing with disaster events should be focused on the aspects of age, professional and field experience to facilitate the allocation of medical personnel, distribution of work, as well as appropriate mobilization at the disaster sites (Faradilla, 2018; Ruslam et al., 2019). While, the public health authorities must continue to monitor changes in situations and conditions to build preventive measures to Coronavirus and its related outbreaks (Lai et al., 2020). As the occurrence of disaster events requires preparedness from health workers, an important aspect to improve this skill is educating them about knowledge, attitudes, and practices of disaster service management (Septiana and Fatih, 2019; Susilawati, 2019).

\section{Health Facilities to Support in Handling COVID-19 Pandemic}

Figure 2 explains the level of distribution of COVID-19 referral hospitals in Indonesia, especially the provinces in Java which becomes the epicenter point for the spread of COVID-19. As a preventive measure in tackling the spread of this pandemic, the government has set the number of COVID-19 referral hospitals in every province including in Java. Furthermore, it has also determined referral hospitals for COVID-19 handling in almost every area in Indonesia. It is a strategic step in identifying conditions of infected patients every day. The existence of referral hospitals in each province will increase affordability to access health facilities and encourage the acceleration of the COVID-19 patient management in each region. Disaster management will run optimally if supported by the adequate

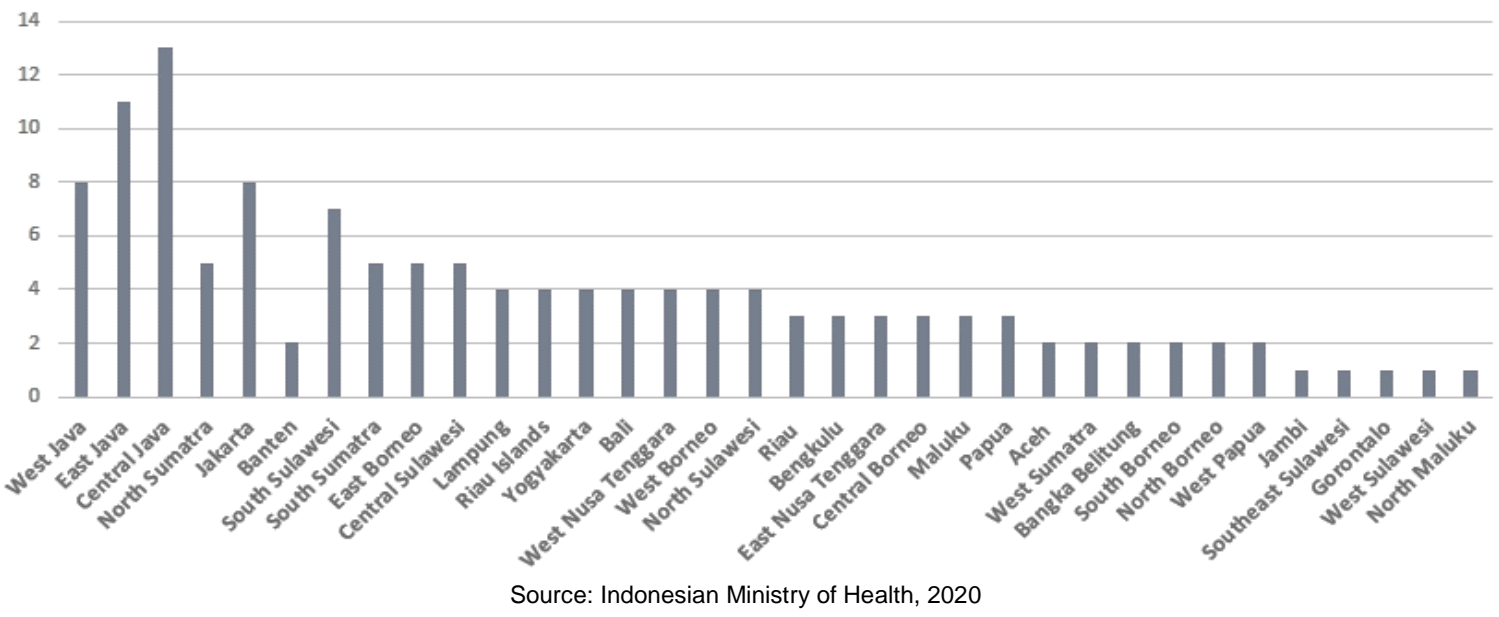

Figure 2. COVID-19 Referral Hospitals in Indonesia (Per March 10, 2020) 


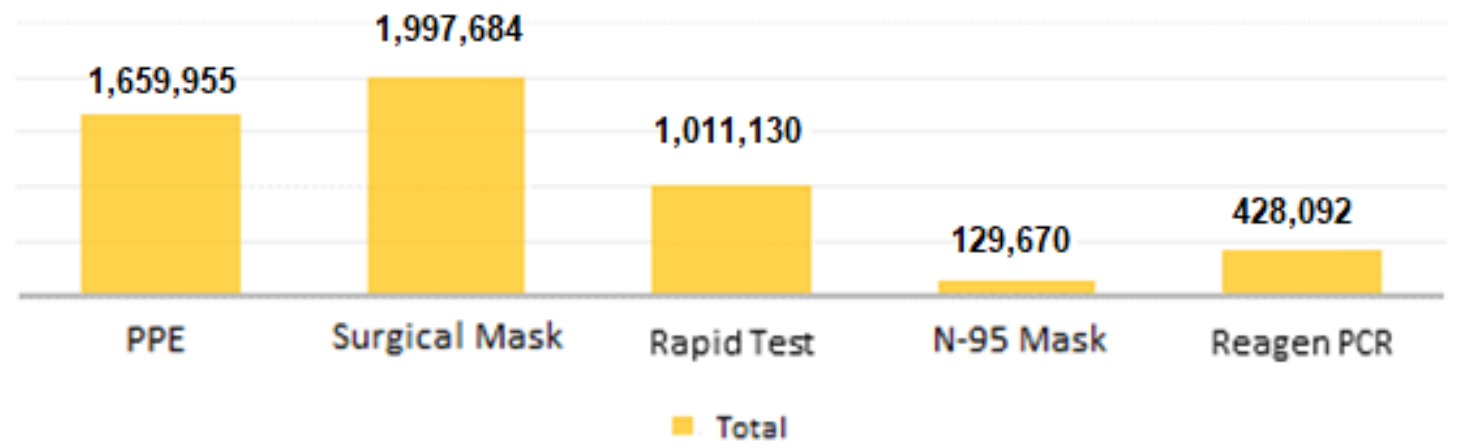

Source: COVID-19 Handling Task Force, 2020

Figure 3. Total Distribution of Medical Devices for COVID-19 Management

(Per May 3, 2020)

number of health service infrastructure and the sufficient number of human resources in emergency services (Musyarofah et al., 2019; Silmi et al., 2019).

Figure 3 shows the most distributed medical equipment is the surgical masks (1,997,684 units), PPE of 1,659,955 units, and rapid test equipment of 1,011,130 units. Surgical masks and PPE are indeed a priority to be immediately distributed to every referral health facility to provide safety for health workers. On the other hand, the availability of standard N-95 masks and PPE must be supported with clear prevention standards and communication and cooperation among stakeholders (Ling et al., 2020). Many positive cases require the full support from medical service facilities with large numbers of health workers. The availability of adequate medical equipment will facilitate health workers to perform medical services to COVID-19 patients. The increasing number of medical devices distributed appropriately to the regional level can reduce the high risk of the pandemic.

From the map in Figure 4, Java Island has a high level of medical device distribution compared to other main islands in Indonesia. As the epicenter of COVID-19 transmission in Indonesia, Java is prioritized to obtain medical devices (West Java, Central Java, East Java, Banten, and DKI Jakarta).

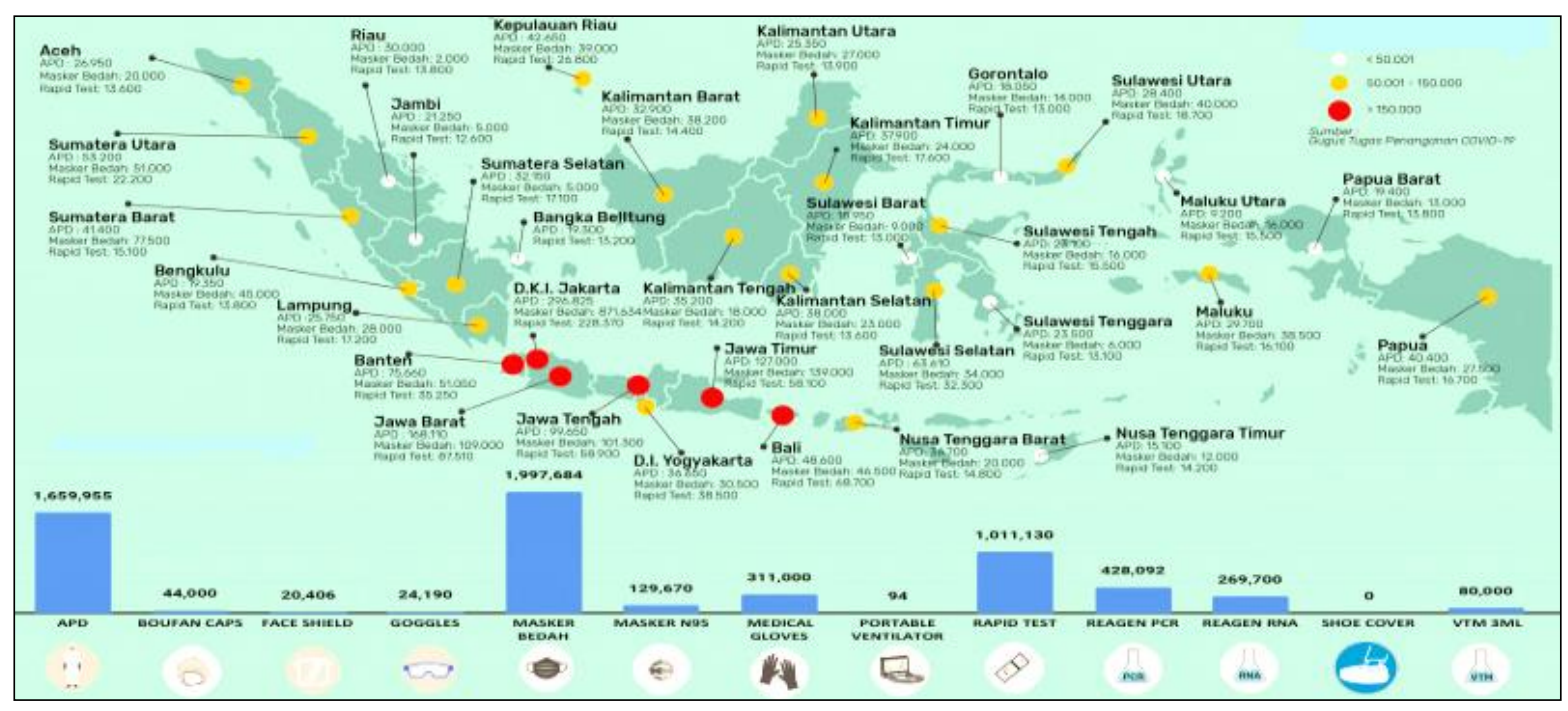

Source: COVID-19 Handling Task Force, 2020

Figure 4. Distribution of Medical Devices in Handling COVID-19 (Per May 3, 2020) 
There have been 150,000 units of medical devices, such as PPE, surgical masks, and rapid tests distributed to the Java-Bali region such as DKI Jakarta, Banten, West Java, Central Java, and East Java is over. Then to other islands such as Sumatra, Kalimantan, Sulawesi, Maluku, West Nusa Tenggara, and Papua, a total of $60,000-150,000$ units have been distributed. Meanwhile, Bangka Belitung, North Maluku, East Nusa Tenggara, and West Papua have received less than 50,000 units [figure 4]. In terms of logistics, the COVID-19 Task Force has also cooperated with other relevant parties in delivering, escorting, and distributing the medical equipment via land, air, and sea transportation to various regions, provinces, districts, and hospitals in Indonesia, from Sabang to Merauke. Effectiveness of disaster management can be achieved by increasing the intensity of coordination and communication (Ariyanto, 2018). Besides, it needs to be supported by more responsive disaster mitigation to the gender-based needs to equip all with an equal capacity of reducing disaster impacts (Nuriana et al., 2017).

This study is among early studies that look at medical service readiness for handling COVID-19 from the policy perspective of patient handling procedures, human health resources, and health facilities. Mandatory operational standard readiness is necessary to guide human health resources to respond cases with appropriate treatment according to correct procedures. Accuracy of disaster management is carried out procedurally by supporting of the complete availability of health facilities since people infected with COVID-19 should obtain rapid and precise health service.

This study provides an overview of public services provided by the government in dealing with the pandemic as a non- natural disaster. However, this study has some limitations as it only uses secondary data in the analysis. Future research on this topic needs to use primary data and triangulation to increase the validity of the results.

\section{CONCLUSION}

As a disaster, COVID-19 that has posed a threat to public health requires health service preparedness seen from readiness in various health aspects, including proper handling procedures. The procedures in handling COVID-19 patients are done through the management of patient placement, environmental management, and visitor management. These are strategic steps in controlling the movement of infected people to prevent the COVID-19 transmission between humans. Medical devices have been distributed to various regions, as well as hospitals in Indonesia, such as 1,997,684 pieces of surgical masks, 1,659,955 units of PPE, and 1,011,130 units of rapid test kits. After having standard procedures and readiness of health facilities, as well as the equal distribution of medical devices, the government needs to pay attention to the readiness of the human resources. The success of implementing health services during the pandemic depends on the human resources at hospitals as the front liners in dealing with COVID-19. Besides, it is also affected by the availability of operational standards and health facilities. Despite an adequate number of human health resources, the availability of health services, information systems, patient handling procedures, and health service governance (good clinical governance) is essential in responding to the pandemic. 


\section{CONFLICT OF INTEREST}

This article does not have any conflict with anyone's interest.

\section{ACKNOWLEDGEMENT}

The authors of the research would like to appreciate all health workers for their dedication and hard work in handling the COVID-19 pandemic in Indonesia.

\section{REFERENCES}

Adnan Shereen, M. et al. (2020) 'COVID19 infection: origin, transmission, and characteristics of human coronaviruses', Journal of Advanced Research. Cairo University, 24, pp. 91-98. doi: https://doi.org/10.1016/j.jare.2020. 03.005 .

Amindoni, A. (2020) Virus corona dalam kurva Jakarta diklaim datar, namun petugas medis ungkap 'fenomena di lapangan tidak berkurang",', BBCNews. Available at: https://www.bbc.com/indonesia/ind onesia-52459813 (Accessed: 25 June 2020).

Ariyanto, D. (2018) 'Koordinasi Kelembagaan Dalam Meningkatkan Efektivitas Badan Penanggulangan Bencana Daerah', Journal of Management Review, 2(1), pp. 161-172.

Arshad Ali, S. et al. (2020) 'The outbreak of Coronavirus Disease 2019 (COVID-19)-An emerging global health threat', Journal of Infection and Public Health. King Saud Bin Abdulaziz University for Health Sciences, 13(4), pp. 644-646. doi: https://doi.org/10.1016/j.jiph.2020. 02.033 .

Berliana, R. and Widowati, E. (2019) 'Tinjauan Sistem Manajemen Keselamatan dan Kesehatan Kerja pada Akreditasi Rumah Sakit', Jurnal Higeia, 3(3), pp. 492-503. doi:

https://doi.org/10.15294/higeia/v3i 3/30254.
Djasr, H. (2020) 'Corona Virus dan Manajemen Mutu Pelayanan Klinis di Rumah Sakit', Journal of Hospital Accreditation, 02(01), pp. $1-2$.

Faradilla, M. (2018) 'Role of Pharmacist in Disaster Management', Pharmaceutical Sciences and Research, 5(1), pp. 14-18.

Gani, Y. (2019). 'Implementasi Pembangunan Zona Integritas dalam Pelayanan Publik Polri', Jurnal IImu Kepolisian, 13(2), pp. 138-147.

Gultom, A. B. (2012) Pengaruh Pengetahuan dan Sikap terhadap Kesiapsiagaan Tenaga Kesehatan Puskesmas Kampung Baru Menghadapi Bencana Banjir di Kecamatan Medan Maimun. Universitas Sumatera Utara. Available at: http://repository.usu.ac.id/handle/1 23456789/33906.

Hadi, H., Agustina, S. and Subhani, A. (2019) 'Penguatan Kesiapsiagaan Stakeholder Dalam Pengurangan Risiko Bencana Gempa Bumi', Jurnal Geodika, 3(1), pp. 30-40.

Heriyanto, H. (2018) 'Thematic Analysis sebagai Metode Menganalisa Data untuk Penelitian Kualitatif', Anuva, 2(3), pp. 317-324. doi: 10.14710/anuva.2.3.317-324.

Huriah, T. and Farida, L. N. (2010) 'Gambaran Kesiapsiagaan Perawat Puskesmas dalam Managemen Bencana di Puskesmas Kasihan I Bantul Yogyakarta', Mutiara Medika, 10(2), pp. 128-134.

Hutagaol, E. K. (2019) 'Masalah Kesehatan Dalam Kondisi Bencara: Peranan Petugas Kesehatan Partisipasi Masyarakat', Jurnal IImiah Kesehatan Institut Medika, 1(1).

Idhom, A. M. (2020) Daftar Kebijakan Jokowi Tangani Pandemi Corona dan Isi Perppu Baru, Tirto. Available at: https://tirto.id/eJYX (Accessed: 2 August 2020).

Jiang, X. et al. (2020) 'Psychological crisis intervention during the outbreak period of new coronavirus pneumonia from experience in 
Shanghai', Psychiatry Research. Elsevier Ireland Ltd, 286, pp. 1-3. doi:

10.1016/j.psychres.2020.112903.

Lai, C. C. et al. (2020) 'Severe acute respiratory syndrome coronavirus 2 (SARS-CoV-2) and coronavirus disease-2019 (COVID-19): The epidemic and the challenges', International Journal of Antimicrobial Agents. Elsevier B.V., 55(3), pp. 1-8. doi: 10.1016/j.jjantimicag.2020.105924

Ling, L. et al. (2020) 'COVID-19: A critical care perspective informed by lessons learnt from other viral epidemics', Anaesthesia Critical Care and Pain Medicine, 39(2), pp. 163-166. doi: 10.1016/j.accpm.2020.02.002.

Lupia, T. et al. (2020) '2019-novel coronavirus outbreak: A new challenge.', Journal of global antimicrobial resistance. Taibah University, 21, pp. 22-27. doi: 10.1016/j.jgar.2020.02.021.

Mas'udi, W. and Winanti, P. S. (2020) Tata Kelola Penanganan COVID19 di Indonesia: Kajian Awal. Cetakan Pe. Yogyakarta: Gadjah Mada University Press.

Musyarofah, S., Muliawati, R. and Mushidah (2019) 'Gambaran Pelayanan Kesehatan Public Safety Center 119', Jurnal IImiah Permas, 9(4), pp. 371-378.

Nanggala, A. (2020) Menyikapi Virus Covid-19, Suara. Available at: https://www.suara.com/yoursay/20 20/03/16/092818/menyikapi-viruscovid-19 (Accessed: 11 June 2020).

Nasution, L. (2020) 'Hak Kesehatan Masyarakat dan Hak Permintaan Pertanggungjawaban Terhadap Lambannya Penanganan Pandemi Global', Adalah Buletin Hukum Dan Keadilan, 4(1), pp. 19-28.

Nuriana, D., Rusyidi, B. and Fedryansyah, M. (2017) 'Mitigasi bencana berbasis sensitive gender', Share Social Work Jurnal, 9(2), pp. 179-194. doi: 10.24198/share.v9i2.25562.
Pane, M., Isturini, I. A. and Wahidin, M. (2018) 'Penanggulangan Krisis Kesehatan di Indonesia', Media Litbangkes, 28(3), pp. 147-156. doi:

https://doi.org/10.22435/mpk.v28i3 .115 .

Purnamasari, A. and Kushandajani. (2019). Peningkatkan Pelayanan Publik Rsup Dr. Kariadi Semarang Yang Akuntabel Dan Anti Korupsi Dalam Mempertahankan Zona Integritas Wilayah Bebas Korupsi. Jurnal IImiah IImu Pemerintahan, $1-10$.

Riana, F. (2020) Permohonan PSBB di Gorontalo dan 5 Daerah ini Ditolak Kemenkes, Nasional Tempo. Available at: https://nasional.tempo.co/read/133 3473/permohonan-psbb-digorontalo-dan-5-daerah-ini-ditolakkemenkes (Accessed: 1 August 2020).

Ruslam, A. W. A. et al. (2019) 'Rekomendasi Tenaga Kesehatan di Lokasi Bencana Memanfaatkan Fuzzy Inference System Model Berbasis Website', SNIMed, pp. 713.

Septiana, M. E. and Fatih, H. Al (2019) 'Hubungan Karakteristik Individu Dengan Kesiapsiagaan Perawat Puskesmas Dalam Menghadapi Bencana Banjir Di Kabupaten Bandung', Jurnal IImiah Kesehatan Keperawatan, 15(1), pp. 1-6. doi: 10.26753/jikk.v15i1.275.

Silmi, N. R., Nur, T. and Purwanti, D. (2019) 'Implementasi Kebijakan Penanggulangan Bencana Daerah Di Kota Sukabumi', JOPPAS: Journal of Public Policy and Administration Silampar, 1(1), pp. 30-40.

Susilawati, A. (2019) Gambaran Kesiapan Tenaga Kesehatan Dalam Manajemen Bencana Di Puskesmas Wilayah Rawan Bencana Di Kabupaten Sumbawa Barat. Universitas Airlangga. Available at: http://repository.unair.ac.id/id/eprin t/84114. 
Tosepu, R. et al. (2020) 'Correlation 725. doi: between weather and Covid-19 10.1016/j.scitotenv.2020.138436. pandemic in Jakarta, Indonesia', Science of the Total Environment, 